\title{
Some southern African entry points into global history
}

\author{
N PARSONS*
}

\begin{abstract}
So-called Global History has taken off in the Unites States to liberate undergraduates from Big Power parochialism, and has been the topic of a major conference held in London in May this year. The key element of Global Studies is to demonstrate the connectedness between different peoples and lands and periods of time. This paper is an attempt to crack the small-end of the egg by starting studies in one familiar region of the world, rather than the big-end approach of starting with general explanations or theory and then relating them back to particulars. It suggests three ways in which Southern Africa could be used as the starting point to throw more general light upon the world's history. First, by taking cues from and asking questions about the latest genetic research which suggests that modern human population dispersal about 60000 years ago began in Angola-Namibia frontier region. Second, by taking cues and asking questions about Indonesian contact with Africa and coastal settlement that may account for significant influences on southern African societies. Third, by tracing the biographies of real individuals whose careers encompass not only southern Africa but other parts of the world and in doing so demonstrate not only interconnectedness of cultural, social, political and economic histories but also significant points of comparison in the experience of global trends and events.
\end{abstract}

Keywords: Global history, deep history, African history, southern Africa, DNA research, biography, Waq-Waq, Early, Middle and late Stone Age, biography.

Disciplines: Global history, African history, southern African studies, archaeology, globalisation studies, DNA studies, biography, anthropology.

\section{Introduction}

So-called Global History (aka 'big history') has taken off in the Unites States to liberate undergraduates from big-power parochialism. Global modules and the Contemporary World Issues course at Champlain College (Vermont) have set the pace in cooperation with colleges in the MiddleEast etc. through the Internet (G Scudder 2009; Esckilsen 2006). 'Writing the History of the Global' was the theme of a major conference held on 21-22 May this year by the British Academy in London (British Academy 2009). The key element of Global History appears to be to demonstrate the connectedness between different peoples and lands over periods of time.

* Professor Neil Parsons, a well-known African historian and author of many academic books and articles, has for many years been a staff member and head of department at the University of Botswana in Gaberones. His email is: nparsons@mopipi.ub.bw. Paper presented on 23 June 2009 at the Southern African Historical Society Biennial Conference (22-24 June 2009) at the University of South Africa's Tshwane Sunnyside Campus. 
Nineteenth-century 'universal history' of the type espoused by Winwood Reade in Cecil Rhodes's 'bible', The Martyrdom of Man (1872) and James Frazer in The Golden Bough (1890) was based on too many inspired guesses. They were guesses that filled the cracks in an impossibly broad range of possible evidence. It was therefore with justification rejected by the early twentieth-century fathers and mothers of modern social/ cultural anthropology. The idea of 'deep history' swung back into favour at the beginning of the twenty-first century, with the 'emerging synthesis' of '[r]apidly accumulating information and new theoretical perspectives in population genetics, historical linguistics, and archaeology ... coming together at last to tell a consistent story of the ancient human past' (Jones 2003: 502).

This paper is an attempt to crack the small-end of the egg, by initiating studies of the global in one familiar region of the world, rather than the big-end approach of beginning with general explanations or theory and then relating them back to the particular. It suggests three ways in which southern Africa might be used as the starting point to throw more light upon the world's big and deep history.

\section{Genes and 'deep history'}

Our first entry point is through the very beginnings of the history of modern humanity - by 'exploring connections between culture areas, genes and languages', identified by Doug Jones (2003) as 'deep history'. We have long suspected that humans originated in Eastern Africa. Genetic research has suggested our common matrilineal ancestor, or African Eve, can be traced back to Eastern Africa about 100,000 years ago - and that our common patrilineal ancestor, or African Adam, can be dated somewhat earlier. The most conspicuous DNA research has been publicized through the Genographic Project funded by the U.S. National Geographic Society and IBM and led by Spencer Wells (Pennisi 2005). But the most exciting recent research has been led by Sarah Tishkoff.

DNA studies led by Wells and more recently Tishkoff (2007) have identified the Hadza people of Tanzania as being the modern group most directly descended from our ancestors at the time of African Eve in about 70,000 BP (before present). But other research has identified a population bottleneck' after about $70,000 \mathrm{BP}$, when the total human population appears to have been reduced to just a few thousand people - from whose descendants the world was colonized after 60,000 BP. The reason for the radical reduction of population appears to have been the explosion in about 75,000 BP of the Toba super-volcano in Sumatra (Indonesia) which blanketed the global atmosphere in thick dust. The resulting 'nuclear winter' radically reduced world temperatures and rainfall, stopped plant photosynthesis, and dried up the East African lakes into mere puddles (Pease 2005).

The really exciting aspect of this DNA research for southern Africa in just the past couple of months, is that Tishkoff's team has identified the modern population who are the most direct ancestors, those from whom the post 60,000 BP world population sprung. They are people who live on the Angolan-Namibian frontier (Tishkoff et al. April 2009). This implies that the dispersal of the modern human population across the world about 60,000 years ago began in the Angolan-Namibian frontier region, and 
spread from there over the Eastern African highlands into Asia.

Simply put, the original three genetic groups of humankind identified by DNA correspond to ancestors of three of the four present-day language families of Africa: (i) Khoesan language-speakers located in southern and Eastern Africa; (ii) Niger-Kordofanian or Niger-Congo languagespeakers located in Central and West Africa; and (iii) Afro-Asian languagespeakers spreading from Eastern Africa. They have given rise to the rest of humankind (Tishkoff et al. April 2009). (The fourth present-day African language family, that of Nilo-Saharan, appears to be as yet unexplained genetically, although prima facie it is intermediate between Afro-Asian and Niger-Kordofanian language families.)

The work by Tishkoff and her team raises fascinating questions, in addition to those of genetics, about the universal human heritage evident at archaeological sites in the Angola-Namibia frontier region. For instance, the extremely rich Middle Stone Age (Howieson's Poort industry) site at $=/$ Gi Pan near the Aha Hills on the northern Namibia-Botswana border has been dated to roughly that period by both TL (thermoluminescence) dating of $77 \mathrm{ka}+/-11$ and eggshell Protein Diagenesis of $75 \mathrm{ka}+/-10$ (Brooks 1977 \& 1990). Much more controversially, in the same geographical area, the =/Gi dating has also been suggested for the giant snake sculpture inside Rhino Cave at Tsodilo Hills (Coulson 2006).

These sites pose questions about what it means be Homo sapiens. Archaeologists have for years vied over finding material evidence of particular moments when early modern people, in this or that place, invented or discovered art and decoration, belief and religion, etc. South Africa takes great pride in the decorated pieces of red ochre found in Blombos Cave on the south coast that are dated to around 77,000 BP (Henshilwood 2002; 2006: 81). But Alison Brooks, who has excavated in East as well as southern Africa, cautions against sudden blinding epiphanies and suggests that the change from Middle to Later Stone Age society was generally gradual (though remote areas such as the southern Cape may be an exception) and was completed by the 30,000 BP date when secure carbon-dating begins (Brooks 1990; McBrearty \& Brooks 2000; Brooks \& Yellen 2005).

Though it has long been obvious to linguists, it has taken considerable time for geneticists (particularly those engaged in U.S. medical research which relied on one 'Yoruba' Haplotype to cover all people of African ancestry) to recognise that Africa has the greatest genetic complexity of any continent. This implies that there are many more twists and turns in Africa's genetic heritage that await explanation. To the north of the Angola-Namibia frontier there is the Pygmy puzzle. Twa or Pygmy people are genetically related to Khoesan people; they may also be the pioneers of the Niger-Congo language family. To the south, the genetic heritage of Khoesan-speaking people and their descendants is more complex than previously assumed. In South Africa, there is a big gap to be filled in the anatomical record between Middle Stone Age, physically robust people and those of the Later Stone Age who were of more gracile build and (as we know) spoke southern San languages.

Research advances in more or less dialectical fashion, as one researcher modifies or challenges or even contradicts another. But historians should keep a weather eye on current research on 'deep history' because (a) it 
has fundamental relevance to who we are as human beings, and how we are all related, with emphasis on the significance of evidence found in southern Africa; (b) the research raises very pertinent questions about how to relate archaeological, genetic and linguistic evidence in relation to received oral traditions - notably what has until now been taught in schools; (c) the latest research findings can convey the scholarly excitement of new discoveries to students who may well have become sceptical of the value of history by the dreary rote teaching of fixed truths.

\section{Wacky theories and the Waq-waq}

The contribution of Indonesian or Malay slaves from Java and neighbouring islands to South African population history, language and religion is relatively well-known. However, to my knowledge there is no research centre dedicated to their study in a South African university. Even less familiar, or relegated simply to the history of Madagascar and off-shore islands, is the history of non-Muslim Indonesian or Malay settlers from North Borneo, referred to in early Islamic sources as WaqWaq or Wak-Wak.

Research into 'ancient' and 'medieval' connections between Africa and Asia have been muddied by scholarly reaction against nineteenthcentury European racist theories of the African past - which argued that anything good or clever in Negro or Bantu Africa must have come with settlers from Asia or from north of the Sahara. Such wacky theories have persisted even today, notably in attributing the 'medieval' stonewalled ruins of southern Africa to the genius of ancient people from Lebanon, Israel, Arabia, or India.

In consequence, historians have maybe become a bit too dismissive of genuine pieces of evidence. I refer here in particular to the imperfectly reconstructed stories of the Lemba and to the Waq-Waq.

DNA studies have shown (what Lemba have always claimed) that a significant number of Lemba men in the Limpopo Province of South Africa bear a typically Jewish Y-chromosome or 'Cohen gene'. And they are related to a string of similar small communities of vashimbadze (ancient traders) dotted sparingly along a route that stretches from the Limpopo through Zimbabwe and Malawi to the Tanzanian coast. Their origin seems to be from the Hadramaut of the Yemen, where many Muslims today probably also carry the 'Cohen gene'. No doubt the vashimbabze were drawn southwards by the eighth to fourteenth century gold trade of Zimbabwe. They were probably also pushed out of Yemen by Sunni persecution of Shi'ite Muslims and Jews (Thomas, Parfitt, et al. 2000). But, no, they did not build Great Zimbabwe, which has dry-stone walling very different from Yemen and the East African coast (Garlake 2002). Whatever their story, the Lemba and similar groups provide a fascinating window into the remote past at a time when the Indian Ocean was the very centre of global trade.

The coming of the Waq-Waq long pre-dated the conversion to Islam of Persian and Arab traders along the East African or Zanj coast, who referred to them dismissively as unclean pig-keepers. The timing of WaqWaq arrivals on the Zanj coast, and their coastal settlements, if any, are as yet unknown to archaeology. But connections between Africa and Asia can be seen as early as $2350 \mathrm{BC}$ in the adoption of African sorghum in 
Indus Valley agriculture (Sinclair 2006: 154), as well as African watermelons and cotton, and the spread of agriculture-associated P. falciparum malaria out of Africa that might well have been even earlier. South-East Asian chickens reached Zanzibar by 850 BC, and Indonesian-Malaysian (originally New Guinean) bananas were being eaten in Cameroon around the same date. The (still undiscovered) port of Rhapta on the Zanj coast was supplying the Himyaritic kingdom of Yemen with 'a great quantity of ivory' in the early centuries AD.

The Waq-Waq sailed in large-capacity, leather-sewn boats with woven sails or in out-rigger sailing canoes and rafts. Their impact on African culture seems to have been considerable. They or other Asians brought with them to Africa domestic pigs and chickens, bananas and sugarcane, and two Asian species of yam. Pollen evidence of such imported plants on the island of Madagascar dates from 550 BC. The Waq-Waq introduced the Indonesian xylophone (thumb-piano) to Africa, and may also have been responsible for the introduction of double-valve bellows and the rotating bow-drill, suggesting their involvement in metallurgy and carpentry.

The historian Christopher Ehret (2002: 188-89) posits that the Waq-Waq may have been induced by commercial opportunities to settle around Rhapta on the northern Tanzania coast, before the downturn in world trade caused that port-city to 'disappear'. Alternatively, they may have been attracted somewhat later, during the upturn in world trade that preceded the rise of Islam in the seventh century, settling around the coast of northern Mozambique. By that time they had also begun to settle across the Mozambique Channel in Madagascar, where the earliest known Malagasy artefacts date from about 650 AD. MozambiqueMadagascar contacts are confirmed by the fact that the name Zimba (leopard folk) is given both to Malagasy people of African descent and to Mozambican-Malawian people in seventeenth century Portuguese sources.

The rise of Zimbabwe gold exports from the central Mozambique coast from about the eighth century attracted Muslim traders. Inevitably these traders came into conflict with the pagan Waq-Waq who were apparently expelled from the coastal area. However, there appears to have been a second wave of settlers from Indonesia, who arrived in Madagascar in about $1100 \mathrm{AD}$ and renewed attacks on the Muslims along the Zanj coast. ${ }^{1}$

\section{History from the side: historical biographies}

You have heard of history from above, and history from below. Now there's history from the side: historical biographies. They offer small sidelights that can fill in the human features of the past, a past left dark by top-

1 Using the evidence of Batibo (1996) and Finalyson (2006: 131) about the close relationship between Sotho-Tswana/ Nguni language with the Makhua language of the southern Tanzania coast, combined with the timing of renewed Waq-Waq attacks and of Shona migrations down to the central Mozambique coast, I have suggested (Parsons 2008) an alternative explanation of Tswana/ Nguni origins around the 12th century to the Huffman (2004) and Hammond-Tooke hypothesis of such origins around Lake Tanganyika. 
lights and footlights. Individuals both make and are made by history, and their biographies can be compared to the 'black boxes' found after an air-crash which help investigators to reconstruct the bigger picture of how the aircraft was performing as it made its way to its destination. In sociological terms, biographies are the situational analyses that plot the networks that connect societies together in the vortices of time and space. $^{2}$

Biographies are often (and should be so) more readable than conventional historical texts. (Nelson Mandela once expressed the ambition to read all the biographies he could after retirement.) They naturally take the narrative form, stolen by novelists, of tracing human foibles from birth through the trials of life to death. The idea of 'biography' has even been purloined by historians such as Peter Ackroyd, author of London: The Biography (2001), who want to treat their subject as an organic whole with a life of its own.

The biographies of people whose careers encompass not only southern Africa but other parts of the world, can enable us to see and feel the inter-connectedness of cultural, social, political and economic histories. They can also offer significant points of comparison in the experience of global trends and events. There have been many biographies of people whose careers link southern Africa with the rest of the world. We need more biographies that link South Africa across borders with the rest of the continent. (However, this genre may be overworked in one respect: I scream inwardly when in a bookstore I see yet another white settler autobiography set in colonial Zimbabwe.)

Here I should confess that the biographical form particularly appeals to a historian like me who likes to accumulate a plethora of odd facts around a subject, and then tries to deduce patterns that link them and bring the past alive in one's mind. I greatly enjoyed the research over many years in many countries for my latest book, a historical biography published by Jacana earlier this month (Parsons 2009a). I hope that the book reads as well.

\section{Bibliography}

Ackroyd, Peter (2001) London: the biography London: Random House

Batibo, Herman (1996) The Role of Language in the Discovery of Cultural History: Reconstructing Setswana Speakers' Cultural Past Gaborone: University of Botswana, Professorial Inaugural Lecture, March 1996

Brooks, A.S. \& J.E. Yellen (1977) 'Archaeological excavations at =/Gi: a preliminary report on the first two field seasons' Botswana Notes and Records, vol. 9, pp. 21-30

Brooks, Allison S. \& 5 others (1990) 'Dating Pleistocene archaeological sites by Protein Diagenesis in ostrich eggshell' Science, vol. 248, 6 April 1990, pp. 60-64

2 I owe this point to my sometime mentor Prof. Jaap Van Velsen at the University of Zambia, one of the Rhodes-Livingstone (Lusaka) school of social anthropologists who founded Network Theory in the 1950s-60s. 
Brooks, Alison S. \& John E. Yellen (2005) 'The Middle Stone Age of East Africa: new discoveries from Ethiopia, Kenya and Tanzania' Abstract of paper no. $9 \&$ unverified notes by Neil Parsons on oral presentation at 12 th Congress of the Pan-African Archaeological Association for Prehistory and Related Studies, Gaborone, 4-6 July

Cunliffe, Barry, Chris Gosden \& Rosemary A. Joyce, eds. (2009) Introduction, pp. xiii-cvii in The Oxford Handbook of Archaeology Oxford: Oxford University Press

Ehret, Christopher (2002) The Civilizations of Africa: A History to 1800 Charlottesville: University Press of Virginia

Esckilsen, Erik (2006) 'Closing the distance: an innovative online program brings U.S. and international students together as global classmates' Champlain View, Spring 2006, pp. 19-22

Finlayson, Rosalie (2006) 'Linguistic relationships: how genetic are they?' chap. 9, pp. 125-38 in Soodyall, Himla Prehistory of Africa: Tracing the Lineage of Modern Man Johannesburg \& Cape Town: Jonathan Ball Publishers

Garlake, Peter (2002) Early Art and Architecture of Africa Oxford: Oxford University Press (History of Art series)

Huffman, Thomas N. (2004) 'The archaeology of the Nguni past' Southern African Humanities, vol. 16, Dec. 2004, pp. 79-111

Jones, Doug (2003) 'Kinship and deep history: exploring connections between culture areas, genes and languages' American Anthropologist, vol. 105, no. 3, pp. 501-514

McBrearty, Sally, \& Alison Brooks (2000) 'The revolution that wasn't: a new interpretation of the origin of modern human behavior' Journal of Human Evolution, vol. 39, pp. 453-563

Parsons, Neil (2008) 'South Africa in Africa more than five hundred years ago: some questions' chap. 3, pp. 41-54 in Swanepoel, Esterhuysen $\&$ Bonner, eds. Five Hundred Years Rediscovered [the maps of figs. 3.1 on p.42 \& 3.2 on p.46 have been incorrectly transposed in printing]

Parsons, Neil (2009a) Clicko the Wild Dancing Bushman Cape Town: Jacana Media

Parsons, Neil (2009b) 'For richer, for poorer: historical reflections on east and southern parts of Africa' in James Robinson \& Jared Diamond, eds. Natural Experiments in History (Cambridge, Mass.: Harvard University Press, in press)

Pennisi, Elizabeth (2005) 'Private Partnership to Trace Human History' Science 15 April 2005, Vol. 308. no. 5720, p. 340

Pikirayi, Innocent (2009) 'The archaeology of sub-Saharan Africa' chap. 24 pp. 723-762 in Barry Cunliffe, Chris Gosden \& Rosemary A. Joyce, eds. The Oxford Handbook of Archaeology Oxford: Oxford University Press

Soodyall, Himla, ed. (2006) The Prehistory of Africa: Tracing the Lineage of Modern Man Johannesburg \& Cape Town: Jonathan Ball Publishers 
Swanepoel, Natalie, Amanda Esterhuysen \& Philip Bonner, eds. (2008) Five Hundred Years Rediscovered: Southern African Precedents and Prospects (500 Year Initiative Conference Proceedings, 2007) Johannesburg: Witwatersrand University Press

Tishkoff, Sarah \& 11 others (2007) 'History of click-speaking populations inferred from mtDNA and Y chromosome genetic variation' Molecular Biology and Evolution, vol. 24, no. 10, 26 July 2007, pp. 2180-2195

Tishkoff, Sarah \& 24 others (2009) 'The genetic structure and history of Africans and African Americans' Science, vol.324, 22 May 2009, pp.1035-1044

Thomas, Mark G., Tudor Parfitt, \& 6 others (2000) 'Y chromosomes travelling south: the Cohen model haplotype and the origins of the Lemba-the "Black Jews of Southern Africa" American Journal of Human Genetics, vol.66, issue 2, Feb.2000, pp. 674-86

\section{Webliography}

British Academy, The UK's National Academy for the Humanities and Social Sciences at http://www.britac.ac.uk/events/2009/globalhistory/index.cfm (Accessed 2009.06.26).

Coulson, Sheila (2006) 'World's oldest ritual discovered?' at www.scienceinafrica.co.za/2006/december/rituals.htm (Accessed)

Pease, Roland (2005) 'Ancient drought changed history' BBC News Weds 7 Dec 2005, 01:39 GMT at $\leq$ http//news.bbc.co.uk/2/hi/science/ nature/4505516/6.stm> (Accessed 15 Nov. 2006

G Scudder, (2009) Global Modules. The Champlain College Modules project: initiating international discussion at globalmodules.blogspot.com (Accessed 2009.06.26). 